\title{
Reconstitution of 305 ribosomal subunits in vitro using ribosome biogenesis factors
}

\author{
DAICHI TAMARU, ${ }^{1,4}$ KAZUAKI AMIKURA, ${ }^{1,4}$ YOSHIHIRO SHIMIZU, ${ }^{2}$ KNUD H. NIERHAUS, ${ }^{3}$ \\ and TAKUYA UEDA ${ }^{1}$ \\ ${ }^{1}$ Department of Computational Biology and Medical Sciences, Graduate School of Frontier Sciences, The University of Tokyo, \\ Chiba 277-8562, Japan \\ ${ }^{2}$ Laboratory for Cell-Free Protein Synthesis, RIKEN Quantitative Biology Center, Suita, Osaka 565-0874, Japan \\ ${ }^{3}$ Institute for Medical Physics and Biophysics, Charité-Universitätsmedizin Berlin, 10117 Berlin, Germany
}

\begin{abstract}
Reconstitution of ribosomes in vitro from individual ribosomal proteins provides a powerful tool for understanding the ribosome assembly process including the sequential incorporation of ribosomal proteins. However, conventional assembly methods require high-salt conditions for efficient ribosome assembly. In this study, we reconstituted $30 \mathrm{~S}$ ribosomal subunits from individually purified ribosomal proteins in the presence of ribosome biogenesis factors. In this system, two GTPases (Era and YjeQ) facilitated assembly of a 30 S subunit exhibiting poly(U)-directed polyphenylalanine synthesis and native protein synthesis under physiological conditions. This in vitro system permits a study of the assembly process and function of ribosome biogenesis factors, and it will facilitate the generation of ribosomes from DNA without using cells.
\end{abstract}

Keywords: biogenesis factors; cell-free translation system; in vitro reconstitution; ribosome; synthetic biology

\section{INTRODUCTION}

Ribosomes are large macromolecules that play a central role in protein synthesis in cells. Their three-dimensional structures were unveiled by a series of crystallographic studies (Ramakrishnan 2002) illustrating the complex of 16S rRNA and Group I (S4, S7, S8, S15, S17, and S20), Group II (S5, S6, S9, S11, S12, S13, S16, S18, and S19), and Group III proteins (S2, S3, S10, S14, and S21). In the reconstitution experiments, the existence of a reconstitution intermediate (RI) with distinctive properties has been demonstrated (Held et al. 1973). The RI, composed of 16 S rRNA and 15 ribosomal proteins, cannot proceed to the maturation step without heat treatment at temperatures exceeding $40^{\circ} \mathrm{C}$. The change of sedimentation of the particles suggested that heat activation induces a conformational change in the $\mathrm{RI}$, resulting in active $30 \mathrm{~S}$ subunit formation. The hierarchical structure of the assembly map of 305 ribosomal subunits is a coarse-grained view under equilibrium conditions, and recent kinetic studies illustrated the presence of several parallel assembly pathways (Mulder et al. 2010; Woodson 2011). Together with these

\footnotetext{
${ }^{4}$ These authors contributed equally to this work.

Corresponding author: amikura@edu.k.u-tokyo.ac.jp

Article is online at http://www.rnajournal.org/cgi/doi/10.1261/rna. 065615.118.
}

results, the existence of the RI as confirmed by earlier studies suggests the presence of a bottleneck state or kinetic trap necessitating activation energy for conformational changes. These aspects make in vitro reconstitution difficult and inefficient.

In contrast to in vitro reconstitution, ribosome assembly proceeds via an extremely rapid and efficient process that is believed to require $<3 \mathrm{~min}$ in the exponential growth phase (Champney 1977). In cells, biogenesis factors and modification enzymes change the local conformation of the precursor 305 subunits. The local conformation change may facilitate the transition to a more energetically stable state (Talkington et al. 2005). Moreover, all processes of ribosome biogenesis in cells proceed smoothly under low concentrations of cations such as $\mathrm{Mg}^{2+}$ and $\mathrm{K}^{+}$, in contrast to the conventional assembly experiments in which aberrantly high concentrations of cations are required.

Two studies on in vitro 305 subunit reconstitution revealed that activation of the RI can be achieved without heat activation. Culver and Noller (1999) demonstrated

(C) 2018 Tamaru et al. This article is distributed exclusively by the RNA Society for the first 12 months after the full-issue publication date (see http://rnajournal.cshlp.org/site/misc/terms.xhtml). After 12 months, it is available under a Creative Commons License (Attribution-NonCommercial 4.0 International), as described at http://creativecommons.org/licenses/by-nc/4.0/. 
that recombinant 305 ribosomal proteins, which were individually expressed in E. coli cells, can be used for $30 \mathrm{~S}$ subunit reconstitution. They also succeeded in activating the $\mathrm{Rl}$ in the presence of protein chaperones instead of heat treatment (Maki et al. 2002). Jewett et al. (2013) developed the iSAT system, which allowed one-step coactivation of rRNA transcription and ribosome assembly in the same compartment. They revealed that functional ribosomal subunits can be assembled under physiological conditions using the S150 fraction of cell extracts. These studies suggested that the conventional heat activation for ribosome assembly could be replaced by the enzymatic factor activity in the in vitro ribosome reconstitution system.

In cells, several factors are known to be involved in the biosynthesis of 30 S subunits (Shajani et al. 2011). In addition to the enzymes responsible for the post-transcriptional modification of rRNA and post-translational modification of ribosomal proteins, GTPase proteins, RNA helicases and other proteins have been suggested by various studies to participate in the assembly process in vivo that occurs cotranscriptionally. However, few studies in which the in vitro assembly experiments of $30 \mathrm{~S}$ subunits were performed using these factors have been reported (Thurlow et al. 2016). Because some in vitro studies indicated that these factors effectively promote the rapid binding of ribosomal proteins to 16S rRNA (Bunner et al. 2010; Thurlow et al. 2016), it is necessary to construct a system using defined biogenesis factors under physiological conditions. By developing such a system, it could be possible to examine efficient $30 \mathrm{~S}$ subunit reconstitution in a cell-like state with defined factors.

For this aim, we examined in vitro $30 \mathrm{~S}$ subunit reconstitution using recombinantly expressed ribosomal proteins and biogenesis factors (Supplemental Table 1). First, S2S21 ribosomal proteins possessing the same sequences as native ribosomal proteins were purified using the small ubiquitin-related modifier (SUMO) fusion method (Malakhov et al. 2004). Using these ribosomal proteins and $16 \mathrm{~S}$ rRNA purified from native $30 \mathrm{~S}$ subunits, we reconstituted $30 \mathrm{~S}$ subunits under high-salt conditions using conventional methods and measured the poly(U)-dependent polyphenylalanine synthesis activity of the reconstituted $30 \mathrm{~S}$ subunits. The activity of reconstituted 30 S subunits was $\sim 30 \%$ of that of purified native $30 S$ subunits, which is consistent with previous results (Culver and Noller 1999). Additionally, reconstituted $30 \mathrm{~S}$ subunits demonstrated full-length translation in the PURE system (Shimizu et al. 2001), although the efficiency was $<50 \%$ of that of purified native $30 \mathrm{~S}$ subunits. We then attempted to reconstitute $30 \mathrm{~S}$ subunits under the physiological conditions using biogenesis factors, which improved the efficacy of reconstitution. In particular, the GTPases Era and YjeO dramatically affected $30 \mathrm{~S}$ subunit assembly.

\section{RESULTS}

\section{Purification of recombinant ribosomal proteins and components of $30 \mathrm{~S}$ subunits}

The individual ribosomal proteins of $30 \mathrm{~S}$ subunits were successfully prepared from E. coli cells. As previously described, ribosomal proteins (S2-S21) were expressed as His-tagged SUMO fusion proteins (Malakhov et al. 2004). The His-tagged SUMO components were removed by the active domain of Ulp1 protease (Ulp1p), which cleaves peptide bonds after the SUMO coding end ( $\mathrm{Li}$ and Hochstrasser 1999). By placing the $\mathrm{N}$-terminal sequence of the ribosomal protein directly downstream from the SUMO coding end, ribosomal proteins were designed to be purified in the same forms as the native ribosomal proteins. Ulp1p cannot cleave sites between the SUMO coding end and a proline residue. Because S7, $\mathrm{S} 19$, and S21 retained a proline residue at their $\mathrm{N}$-termini, the proline residues of these proteins were replaced by alanine residues for efficient cleavage. All SUMO fusion ribosomal proteins were overexpressed and purified by $\mathrm{Ni}^{2+}$ column chromatography, digested by Ulp1p, and then again subjected to $\mathrm{Ni}^{2+}$ column chromatography to remove SUMO components and His-tagged Ulp1p. In cases in which the ribosomal proteins were insoluble, which is consistent with previous results (Culver and Noller 1999), we used urea to solubilize the proteins (Supplemental Information).

The purity of prepared ribosomal proteins was analyzed by SDS-PAGE (Fig. 1), and their molecular weights were determined by matrix-assisted laser desorption ionization-time of flight mass spectrometry (MALDI-TOF MS)

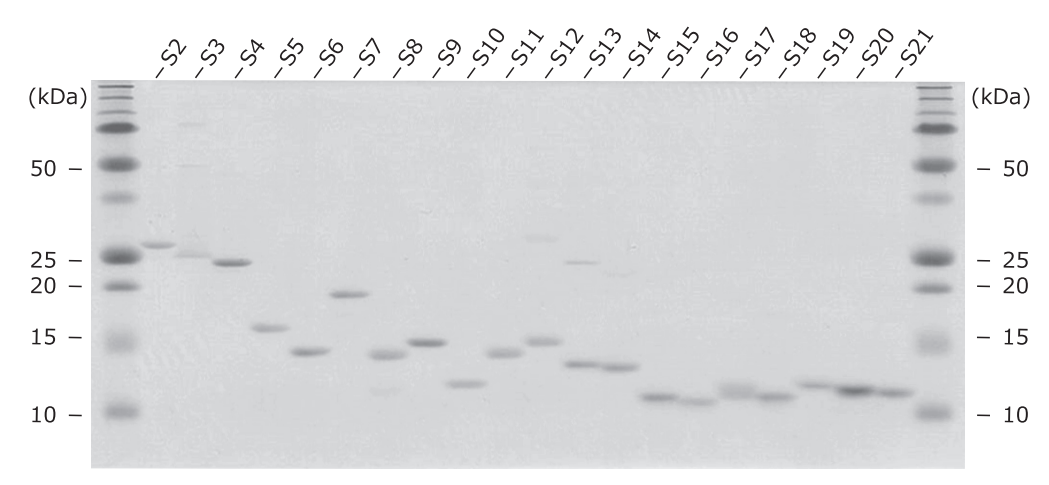

FIGURE 1. S2-S21 30S subunit ribosomal protein after removal of the His tag and SUMO. Purified S2-S21 30S subunit ribosomal proteins after two-step chromatography (Supplemental Information) were subjected to 15\% SDS-PAGE. 
(Supplemental Table 2). All mass spectra of S2-S21 30S subunit ribosomal proteins were measured as described by Talkington et al. (2005). In our study, mass spectra were calibrated using native ribosomal proteins. As a result, all purified recombinant ribosomal proteins, except S11 and S20, were confirmed with the correct molecular weights by MALDI-TOF-MS. The estimation of molecular weight indicated that S5 and S18 were not acetylated and that S12 was not methylthiolated, which differed from the native forms.

\section{Reconstitution of 305 subunit components under high-salt conditions}

We next examined a conventional $30 \mathrm{~S}$ subunit reconstitution method using purified ribosomal proteins. We followed the method described by Culver and Noller (1999), which requires heat activation of the $\mathrm{Rl}$ at $42^{\circ} \mathrm{C}$ under highsalt conditions. The resultant reconstituted $30 \mathrm{~S}$ subunits exhibited similar sedimentation to the native $30 \mathrm{~S}$ subunits in SDG analysis (Fig. 2A). The $30 \mathrm{~S}$ fractions were collected and purified for analysis by SDS-PAGE. The reconstituted 30 Subunits contained all S2-S21 ribosomal proteins (Fig. 2B), indicating that reconstitution of $30 \mathrm{~S}$ subunits containing all $30 \mathrm{~S}$ subunit proteins was successful using purified components. The band intensity of S2 of the reconstituted $30 \mathrm{~S}$ was weaker than that in native 30S, suggesting heterogeneity in the stoichiometry of ribosomal proteins in the reconstituted $30 \mathrm{~S}$ subunits.

\section{Evaluation of the activity of the reconstituted 30 S subunits}

The poly $(U)$-directed polyphenylalanine synthesis activity of the reconstituted $30 \mathrm{~S}$ subunits was evaluated. The activity of the reconstituted $30 \mathrm{~S}$ subunits was $\sim 30 \%$ of that of the native $30 \mathrm{~S}$ subunits (Fig. $2 \mathrm{C}$ ). We also tested the effect of adding $\mathrm{S} 1$ ribosomal protein on the activity of the reconstituted $30 \mathrm{~S}$ subunit (Supplemental Fig. 1). Addition of the S1 protein to the reconstituted $30 \mathrm{~S}$ subunits increased their activity by more than twofold, consistent with previous studies reporting that the polyphenylalanine synthesis activity of S1-depleted E. coli $30 \mathrm{~S}$ subunits is enhanced by the addition of S1 (Roberts and Rabinowitz 1989). The entire translation activity of the reconstituted 305 subunits was further analyzed on the basis of DHFR synthesis in the PURE system (Fig. 2D), which demonstrated that the reconstituted subunits could synthesize DHFR and that this activity was increased upon adding S1. The reconstituted $30 \mathrm{~S}$ subunits with S1 protein exhibited $\sim 30 \%$ of the activity of native 30 s subunits, whereas those without S1 protein were $<10 \%$ of the activity of native $30 \mathrm{~S}$ subunits.
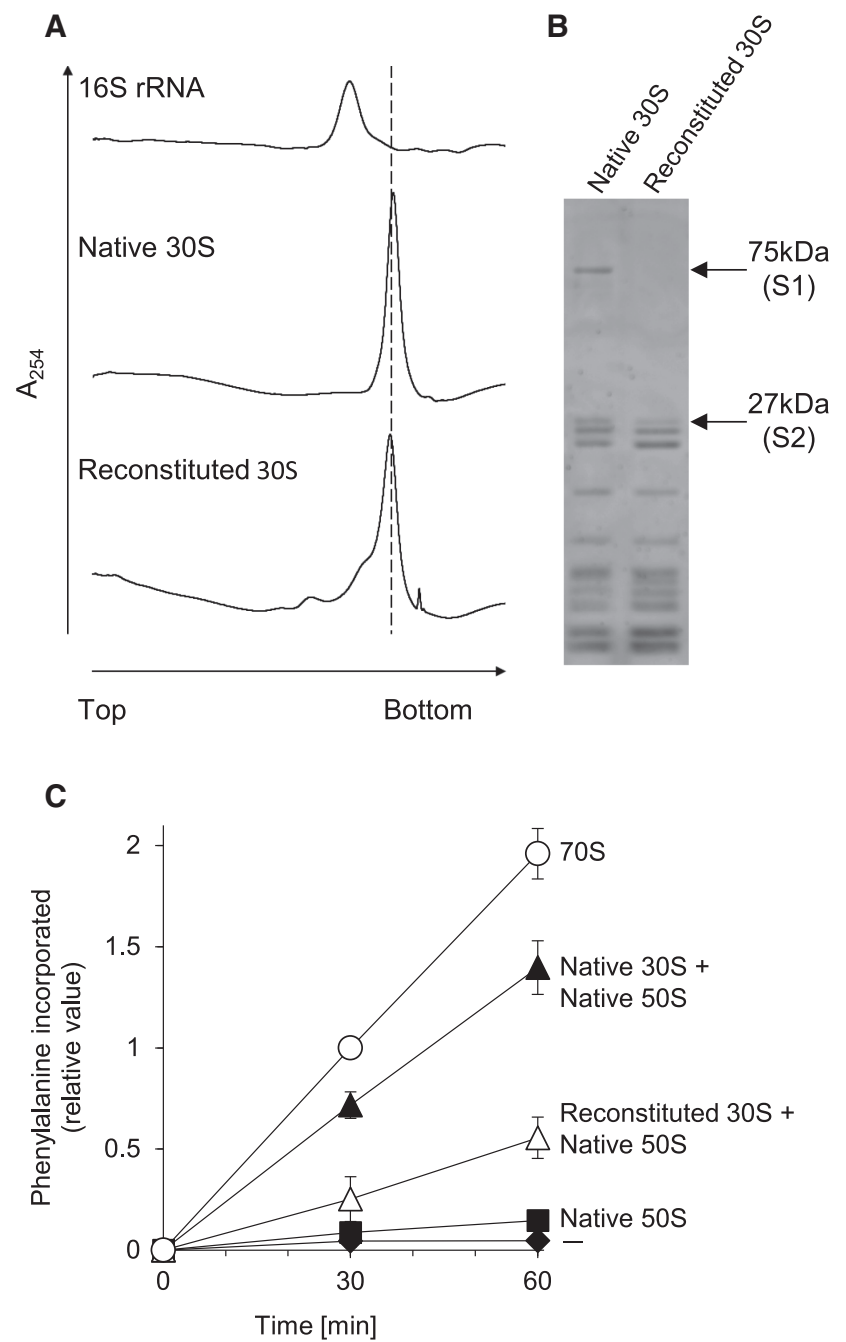

D

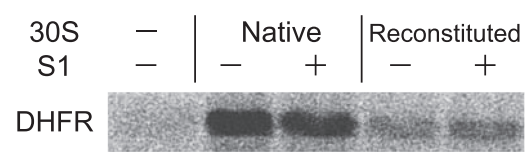

FIGURE 2. Analysis of $30 \mathrm{~S}$ particles reconstituted using conventional methods. (A) Reconstituted mixtures were analyzed by 10\%-40\% SDG analysis. Native $16 \mathrm{~S}$ rRNA and native $30 \mathrm{~S}$ subunits were analyzed as controls. The lines show the peaks of native $16 \mathrm{~S}$ rRNA, native $30 \mathrm{~S}$ subunits, and reconstituted $30 \mathrm{~S}$ particles, using heat activation. (B) Purified reconstituted particles were analyzed by $15 \%$ SDS-PAGE and stained by SYPRO Orange (Invitrogen). Native $30 \mathrm{~S}$ subunit proteins were loaded in the left lane, and 305 particles reconstituted via heat activation were loaded in the right lane. (C) Synthesized polyphenylalanine labeled with ${ }^{14} \mathrm{C}$ was detected using a liquid scintillation counter. The values of ${ }^{14} \mathrm{C}$-phenylalanine incorporation were standardized (the value of ${ }^{14} \mathrm{C}$ phenylalanine incorporation by native $30 \mathrm{~S}$ and $50 \mathrm{~S}$ subunits after $30 \mathrm{~min}$ was determined as 1). ${ }^{14} \mathrm{C}$-phenylalanine incorporation by various subunits is denoted as follows: native 70S, O; native $30 \mathrm{~S}$ and $50 \mathrm{~S}$ subunits, $\mathbf{4}$; reconstituted $30 \mathrm{~S}$ subunits and native $50 S$ subunits, $\Delta$; native $50 S$ subunits, $\mathbf{m}$; and no ribosomes, ^. The bar shows the standardized values. (D) Dihydrofolate reductase (DHFR) synthesis in the PURE system using 30 S subunits reconstituted via heat activation. 


\section{PURE direct assay: in vitro reconstitution of $30 \mathrm{~S}$ subunits with biogenesis factors}

In addition to the conventional method, we tried to identify more physiological ribosome reconstitution conditions without heat activation or high-salt conditions, such as the iSAT system, which enabled the integration of rRNA transcription and ribosome assembly (Jewett et al. 2013). For this purpose, we attempted to integrate ribosome assembly and the subsequent translation reaction by the assembled 305 subunits in a single tube using a buffer condition similar to that of the PURE system (Shimizu et al. 2005). We defined $200 \mathrm{mM} \mathrm{K}^{+}$and $7.5 \mathrm{mM} \mathrm{Mg}^{2+}$ as the middle-salt condition and 150 $\mathrm{mM} \mathrm{K}^{+}$and $5 \mathrm{mM} \mathrm{Mg}^{2+}$ as the lowsalt condition. The $\mathrm{Mg}^{2+}$ concentration was verified to not inhibit poly (U)-directed polyphenylalanine synthesis (Supplemental Fig. 2).

We examined whether biogenesis factors facilitate 305 subunit assembly in the absence of heat activation. Eight enzymes or factors including modification enzymes were selected, purified (Supplemental Fig. 3), and evaluated in an assay system in which successive 305 subunit assembly and poly(U)-directed polyphenylalanine synthesis were performed in a test tube (PURE direct assay). In the absence of biogenesis factors, the addition of both $16 \mathrm{~S}$ rRNA and ribosomal proteins did not affect ${ }^{14} \mathrm{C}$-phenylalanine incorporation under the low-salt condition, whereas its incorporation was increased in the middle-salt condition, suggesting 305 subunit assembly is promoted by $16 \mathrm{~S}$ rRNA and ribosomal proteins in the middle-salt condition (Fig. 3A). In contrast, in the presence of biogenesis factors, the addition of both 16S rRNA and ribosomal proteins increased the ${ }^{14} \mathrm{C}$ phenylalanine incorporation under both conditions, suggesting the biogenesis factors promoted the $30 \mathrm{~S}$ subunit assembly even under lowsalt conditions. We have no explanation for the high background, but it is likely that contamination of $30 \mathrm{~S}$ sub- units in the 50S fraction in PURE direct assay caused this high background.

The $30 \mathrm{~S}$ subunit assembly in the low-salt condition was further verified via SDG analysis and two-step PURE direct
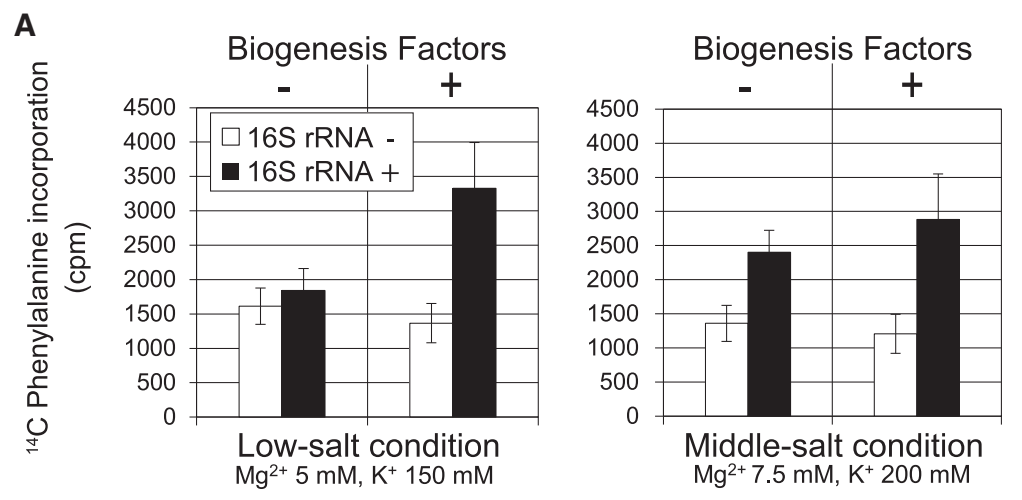

\section{B}
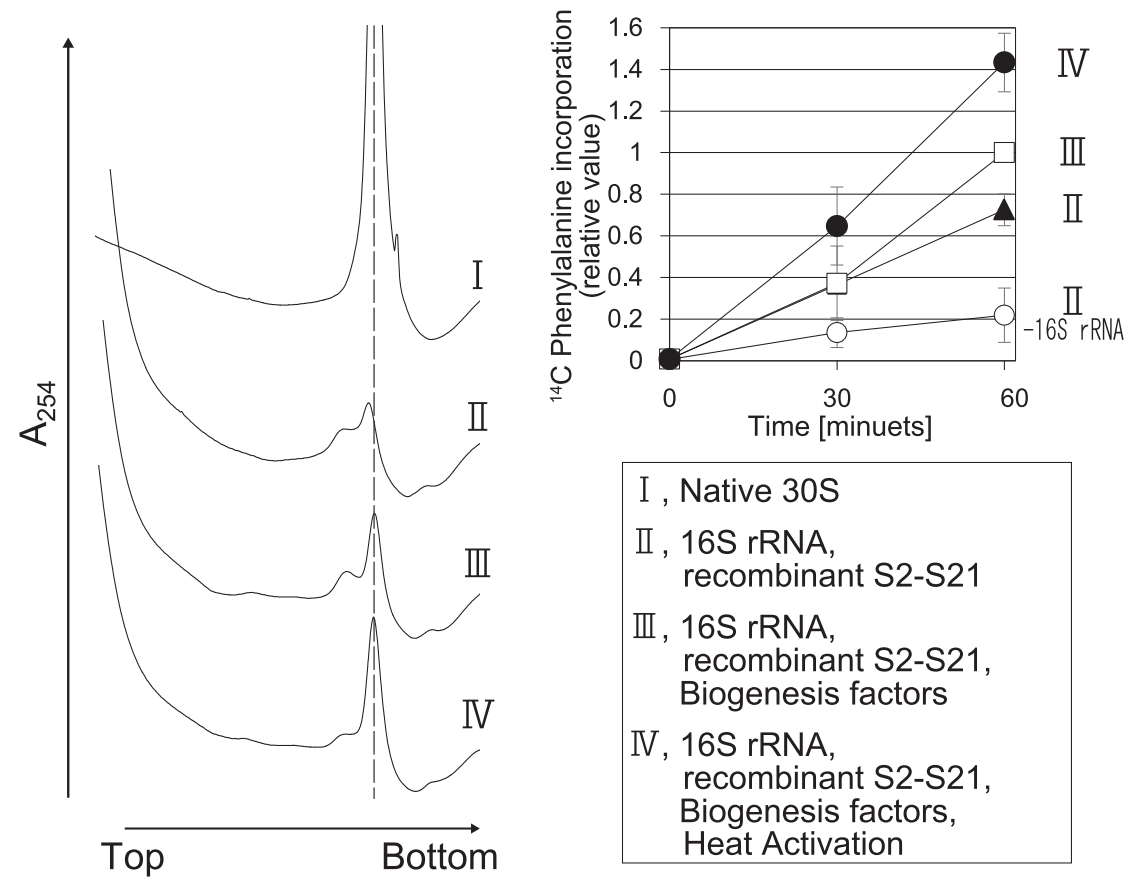
I , Native $30 \mathrm{~S}$
II , 16S rRNA, recombinant S2-S21
III , 16S rRNA, recombinant S2-S21, Biogenesis factors
IV , 16S rRNA, recombinant S2-S21, Biogenesis factors, Heat Activation

FIGURE 3. (A) ${ }^{14} \mathrm{C}$-phenylalanine incorporation during a 1-h period was examined using the PURE direct assay in the presence or absence of biogenesis factors. Error bars indicate standard deviations. ${ }^{14} \mathrm{C}$-phenylalanine incorporation in the absence of native $16 \mathrm{~S}$ rRNA is shown by the white bar, and that with native 16S rRNA and recombinant ribosomal proteins (S2-S21) is denoted by the black bar. (B) Reconstituted $30 \mathrm{~S}$ particles in a low-salt condition $\left(5 \mathrm{mM} \mathrm{Mg}^{2+}\right.$, $150 \mathrm{mM} \mathrm{K}^{+}$) were analyzed by SDG analysis (Materials and Methods). Native 30S subunits are shown in line I as a control. The profile of $30 \mathrm{~S}$ particles reconstituted using native $16 \mathrm{~S}$ rRNA and S1-S21 ribosomal proteins is shown as line II. The profiles of $30 \mathrm{~S}$ particles reconstituted using native 16S rRNA, S1S21 30S subunit ribosomal proteins and biogenesis factors without and with heat activation at $42^{\circ} \mathrm{C}$ are shown as lines III and IV, respectively. The right graph shows the effect of heat-treatment analyzed by two-step PURE direct assay. In this experiment, the $30 \mathrm{~S}$ subunit assembly reaction was performed for $40 \mathrm{~min}$ at $37^{\circ} \mathrm{C}$ without translation mixture, including components such as native $50 \mathrm{~S}$ subunits, poly $(\mathrm{U}),{ }^{14} \mathrm{C}$-phenylalanine and elongation factors. Subsequently, the assembly reaction was additionally performed for $20 \mathrm{~min}$ at $37^{\circ} \mathrm{C}$ (II-16S rRNA, II, III) or $42^{\circ} \mathrm{C}$ (IV) to analyze the effect of heat-treatment. After the assembly reaction, the level of polyphenylalanine synthesis was monitored at 30 and 60 min after the addition of the translation mixture. 
assay. In the absence of biogenesis factors, a peak with smaller sedimentation compared to that of the native 30 S subunits was observed (Fig. 3B, II), suggesting most of the formed particles are those that stopped developing during 305 subunit formation. When the biogenesis factors were added to the reconstitution mixtures, the peak for immature particles shifted to the $30 \mathrm{~S}$ position (Fig. $3 \mathrm{~B}, \mathrm{III})$, and when heat activation was performed in the presence of biogenesis factors, a sharp and large peak at the $30 \mathrm{~S}$ position was observed (Fig. 3B, IV). The results indicate that biogenesis factors facilitate in vitro $30 \mathrm{~S}$ subunit assembly. Activities of assembled 305 subunits, which were analyzed by the two-step PURE direct assay (in Fig. $3 \mathrm{~B})$, were nearly in proportion to the intensity of the peak at the $30 \mathrm{~S}$ position in the SDG analysis. Together with the result of PURE direct assay, in vitro 30 S subunit reconstitution can be performed using biogenesis factors under low-salt conditions with $150 \mathrm{mM} \mathrm{K}^{+}$and $5 \mathrm{mM} \mathrm{Mg}^{2+}$.

\section{The effects of ribosome biogenesis factors on in vitro $30 \mathrm{~S}$ subunit reconstitution}

The effect of individual biogenesis factors and DnaKDnaJ-GrpE was examined using the PURE direct assay (Fig. 4A). In this experiment, Era displayed the strongest effect on 30 S subunit assembly, whereas YjeO and RimP slightly enhanced assembly. Era and $\mathrm{YjeO}$ are responsible for the late stage of assembly. RimP was also identified as a biogenesis factor involved in the late stages of $30 \mathrm{~S}$ subunit biogenesis (Bunner et al. 2010).

Previous reports indicated that two GTPases worked effectively in in vitro 305 subunit reconstitution (Thurlow et al. 2016) and that the GTPase activity of YjeQ is enhanced in the presence of mature 305 or 705 subunits, suggesting that these subunits may function as GTPase-activating fac- tors (Daigle and Brown 2004). We observed the GTPase activity of YjeO depending on the $30 \mathrm{~S}$ or $70 \mathrm{~S}$ subunits under the low-salt concentration (Supplemental Fig. 4), which is consistent with the previous report. In contrast, the increase of GTPase activity upon the addition of ribosomes was not observed for Era at $20 \mathrm{nM}$ concentration. This is consistent with previous reports that $50 \mathrm{nM}$ each of Era and subunits did not enhance GTPase activity (Thurlow et al. 2016). Additionally, we examined the time-dependent increase of ${ }^{14} \mathrm{C}$-phenylalanine incorporation in the PURE direct assay in the presence of Era, and it turned out that Era increased the efficiency of in vitro 305 subunit reconstitution under the low-salt condition (Fig. 4B).

\section{DISCUSSION}

In this study, ribosomal proteins were prepared separately by expressing the proteins in their SUMO fusion forms followed by Ulp1 protein digestion. The fusion with SUMO has advantages to prevent recombinant ribosomal proteins of aggregation and of degradation during the purification procedure. In addition, the removal of SUMO with UIp1 can generate protein with native amino acid sequence, which is different from the digestion by TEV protease or thrombin. The amino acid sequence of recombinant ribosomal proteins after cleavage is expected to be identical to that of the native ribosomal proteins, including $\mathrm{N}$-terminal methionine excision (Arnold and Reilly 1999), except when proline is located at the C-terminal end of the Ulp1 cleavage site. As S7, S19, and S21 have proline residues at their $\mathrm{N}$-termini, proline was replaced by alanine in these proteins. As $\mathrm{N}$-terminal acetylation is not introduced in this method, the influence of these post-translational modifications on the process of reconstitution and the effect on ribosome activity can be evaluated, which differs from
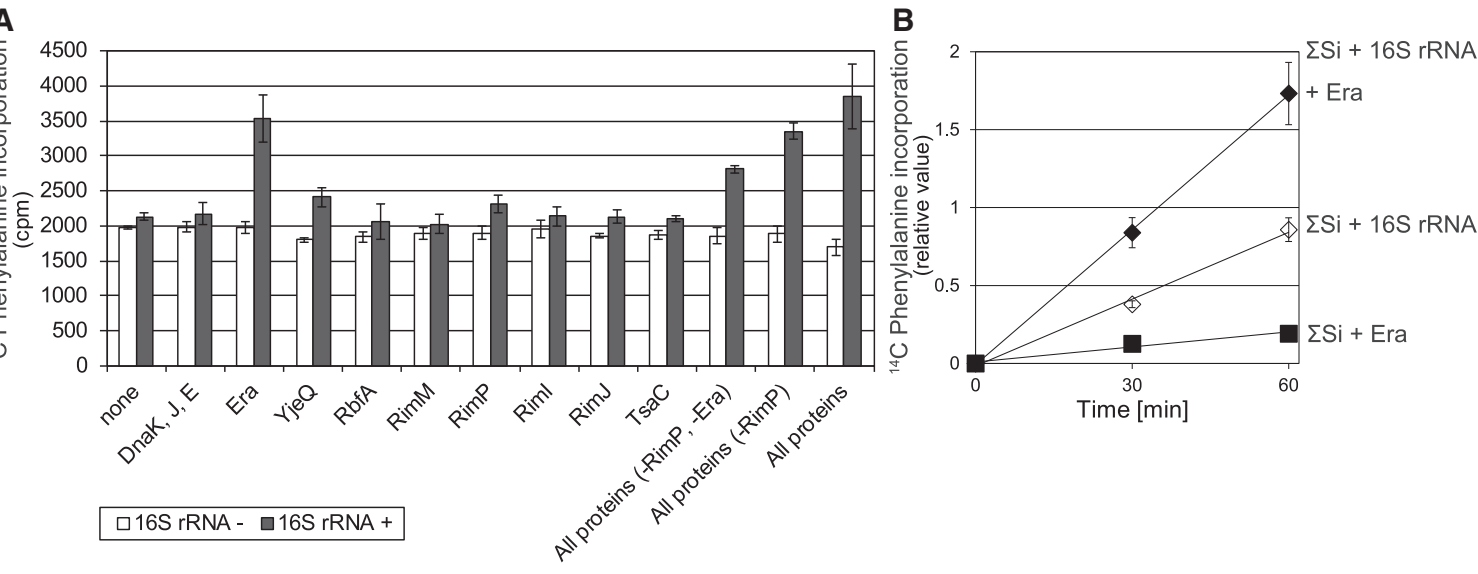

FIGURE 4. The effects of the biogenesis factors. (A) The effect of each biogenesis factor or their combination was assayed using a PURE direct assay. (B) Analysis of the effect of Era in the two-step PURE direct assay. The $30 \mathrm{~S}$ subunit assembly reaction was performed for $60 \mathrm{~min}$ at $37^{\circ} \mathrm{C}$ without translation mixtures, including components such as native $50 \mathrm{~S}$ subunits, poly(U), ${ }^{14} \mathrm{C}$-phenylalanine, and elongation factors. After the assembly reaction, the level of polyphenylalanine synthesis was monitored 30 and $60 \mathrm{~min}$ after addition of the translation mixture. 
Culver's work, in which they believed that N-terminal acetylation might be substoichiometrically introduced (Culver and Noller 1999). The purification procedure using the affinity tag is advantageous due to the uniform preparation procedure regardless of the properties of the proteins. However, most ribosomal proteins are inclined to aggregate during the purification procedures from overexpressed cells as reported by Culver and Noller (1999). This propensity of ribosomal proteins is considered to be caused by the exposure of positively charged amino acids on the surface to rRNA. In particular, S9, S10, S11, and S18 had high insolubility, and they were stored in a urea-containing solution. To purify such proteins in a solubilized state, it is necessary to include steps such as supplying partner nucleic acids as decoys or coupling RNA transcription with ribosome assembly as done in the iSAT system.

Using recombinant ribosomal proteins, $30 \mathrm{~S}$ reconstitution was performed in a conventional manner under a high-salt condition. The reconstituted particles displayed a similar sedimentation pattern as native 30S. The addition of S1 protein to reconstituted particles enhanced the level of polyphenylalanine synthesis to $~ 80 \%$ of that of native $30 S$ (Supplemental Fig. 1). Roberts and Rabinowitz reported that poly(U)-directed polyphenylalanine synthesis was activated in E. coli 30 S subunits lacking S1 by the addition of the protein (Roberts and Rabinowitz 1989). In Culver's report, whereas the translational activity of ribosomes reconstituted from TP30 proteins was $79 \%$ of that of native ribosomes, those reconstituted from recombinant proteins exhibited $34 \%$ of the activity of native ribosomes. Because they did not use S1 protein in their reconstitution experiment from recombinant proteins, the discrepancy might be caused by the presence or absence of $\mathrm{S} 1$ protein, which is consistent with our present observation (Fig. 2C).

In contrast to poly(U)-directed translation, the efficiency of DHFR synthesis by the reconstituted subunits was relatively low compared to that of native $30 \mathrm{~S}$ (Fig. 2D). The pattern of ribosomal proteins in SDS-PAGE for the obtained 305 particles could explain the low productivity (Fig. 2B). Specifically, the band corresponding to S2 was thin, and the proportion of fully reconstituted 305 was low. According to Nomura's 305 subunit assembly map, S2 binds 16S rRNA in the final step, indicating that our reconstituted 305 subunits are probably composed of various immature complexes that stopped developing before S2 binding. Although SDS-PAGE analysis failed to detect the distinct depletion of particular ribosomal proteins, it is plausible that the reconstituted 305 sample contains heterogeneous immature particles.

Recently, heterogeneity of immature particles formed in mutant cells was demonstrated using quantitative mass spectrometry and single-particle cryo-electron microscopy (Davis et al. 2016). The methods are also applicable to the in vitro reconstituted particles and may provide insight into the ribosome assembly process for efficient reconstitution in vitro. Analyses of in vitro reconstituted particles using these methods are expected to be useful, because intermediate particles of early stages that are difficult to isolate from cells can be prepared. The combination of these analyses and examination of translational activities of reconstituted subunits will allow us to elucidate function of biogenesis factors and to optimize assembly conditions, such as biogenesis factors, ion-strength, and temperature.

To investigate the activities of $30 \mathrm{~S}$ subunit biogenesis factors, we developed the PURE direct assay system, which allowed us to evaluate their effects on in vitro $30 \mathrm{~S}$ subunit assembly. We found that Era and YjeO have distinct effects on in vitro $30 \mathrm{~S}$ subunit assembly (Fig. 4A). Both GTPases were identified decades ago. Early genetic studies suggested that Era and $\mathrm{YjeO}$ were involved in $30 \mathrm{~S}$ subunit biogenesis because their mutant phenotype often exhibit $30 \mathrm{~S}$ subunit assembly defects. Later biochemical experiments revealed that their GTPase activities are activated by $16 \mathrm{~S}$ rRNA and 30 S subunits (Sharma et al. 2005). Cryo-electron microscopy images suggested that Era binds to the $16 \mathrm{~S}$ rRNA 3'-terminal region where S1 protein binds (Sharma et al. 2005). Tu et al. (2009) suggested Era serves as a chaperone for processing, maturation of $16 \mathrm{~S}$ rRNA and a check point for assembly of the $30 \mathrm{~S}$ ribosomal subunit. Our experimental data also showed that Era can work before S1 binding. In this study, we observed that Era promotes $30 S$ subunit assembly in vitro by associating with mature $16 \mathrm{~S}$ rRNA possessing modified nucleotides. Furthermore, this experiment was performed using a half-molar ratio of $30 \mathrm{~S}$ subunit biogenesis factors to $16 \mathrm{~S}$ rRNA, which is a much higher concentration than that in cells. Under these conditions, multiple pathways for completing 305 subunit assembly were selected and passed by RIs, which take the easiest path in $30 \mathrm{~S}$ subunit assembly landscapes. In vitro $30 \mathrm{~S}$ subunit assembly using purified components, undermodified ribosomal proteins and mature $16 \mathrm{~S}$ rRNA is highly accelerated by Era and RimP, and these two genes could not be replaced by any other factors. These findings are consistent with previous observations that RimP could not be rescued by any other biogenesis factor (Nord et al. 2009) and that Era remains bound to the immature $30 \mathrm{~S}$ subunit throughout several stages of assembly with other biogenesis factors (Mulder et al. 2010).

The achievement of de novo synthesis of ribosomes using cell-free translation is desired in the field of synthetic biology. In addition, it would facilitate the development of an artificial evolution system of functional ribosomes and permit the bottom-up synthesis of minimal cells. At present, it is possible to reconstitute functional $30 \mathrm{~S}$ subunits from TP30 and cotranscribed 16S rRNA without modification under physiological conditions, although the efficiency of the subunits is lower than that when native $16 \mathrm{~S}$ rRNA is used (Jewett et al. 2013). Unlike $30 \mathrm{~S}$ subunits, the reconstitution of catalytically active $50 \mathrm{~S}$ subunits using in vitro transcribed 23S rRNA under physiological 
conditions has not been realized. These results indicate that modifications within native rRNA are important for reconstructing ribosomes efficiently under physiological conditions as well as increasing translation efficiency and fidelity. Therefore, it will be necessary to develop an in vitro system for incorporating modified nucleotides into transcribed rRNAs or perform the selection of highly active 23S rRNA mutants via artificial evolution. Moreover, for the de novo synthesis of ribosomes, the expression of more than 50 types of ribosomal proteins and rRNA transcripts must be combined simultaneously. Church demonstrated that individual ribosomal proteins can be expressed in cell-free translation systems and that $30 \mathrm{~S}$ subunits can be reconstituted using ribosomal proteins to prepare using cell-free translation systems ( $\mathrm{Li}$ et al. 2017). Similarly, we have already optimized the simultaneous expression of individual ribosomal proteins using a cell-free translation system (data not shown). These studies will facilitate the de novo synthesis of ribosomes.

\section{MATERIALS AND METHODS}

\section{Protein purification procedure}

Ribosomal proteins were expressed in E. coli cells in their Histagged SUMO fusion forms and purified using Ni-column chromatography. The SUMO portion was removed via Ulp1 digestion, and ribosomal proteins were further purified using column chromatography. Details of the procedure are described in the Supplemental Information.

\section{Preparation of native components in ribosomes}

Tightly coupled ribosomes were purified from E. coli A19 cells via sucrose density gradient (SDG) centrifugation as previously described (Spedding 1990). 70 S ribosomes were diluted in SE buffer [20 mM Hepes- $\mathrm{KOH}$ ( $\mathrm{pH}$ 7.6), $30 \mathrm{mM} \mathrm{NH}_{4} \mathrm{Cl}, 1 \mathrm{mM} \mathrm{Mg}(\mathrm{OAc})_{2}, 7$ $\mathrm{mM}$ B-mercaptoethanol]. Diluted $70 \mathrm{~S}$ ribosomes were loaded onto $10 \%-40 \%$ sucrose gradients in SE buffer and ultracentrifuged in an SW28 rotor at 18,000 rpm (Beckman Coulter) for 16 $\mathrm{h}$ at $4^{\circ} \mathrm{C}$. The fractions exhibiting similar sedimentation distances as $30 \mathrm{~S}$ and $50 \mathrm{~S}$ subunits were collected by a piston gradient fractionator (BioComp Instruments, Inc.) and subjected to further ultracentrifugation in a $45 \mathrm{Ti}$ rotor at 40,000 rpm (Beckman Coulter) for $36 \mathrm{~h}$ at $4^{\circ} \mathrm{C}$ for recovery. $30 \mathrm{~S}$ and $50 \mathrm{~S}$ subunits were resolved in ribosome buffer $(20 \mathrm{mM}$ Hepes- $\mathrm{KOH}[\mathrm{pH} 7.6], 30$ $\mathrm{mM} \mathrm{KCl}, 6 \mathrm{mM} \mathrm{Mg}(\mathrm{OAc})_{2}, 7 \mathrm{mM}$ B-mercaptoethanol). Aliquots of the subunits were frozen at $-80^{\circ} \mathrm{C}$. Native $16 \mathrm{~S}$ rRNA was extracted from $30 \mathrm{~S}$ subunits using phenol and chloroform in the presence of $270 \mathrm{mM} \mathrm{KOAc} \mathrm{(pH} \mathrm{5.2).} \mathrm{RNA} \mathrm{was} \mathrm{precipitated} \mathrm{by}$ the addition of 0.9 volumes of 2-propanol and collected by centrifugation. Pellets were washed with $80 \%$ ethanol, and supernatants were removed after centrifugation, dried under vacuum, and resuspended in Milli-Q water. The concentration of native $16 \mathrm{~S}$ rRNA was measured using Gene Spec I (HITACHI). Aliquots of the RNA samples were frozen at $-80^{\circ} \mathrm{C}$.

\section{Reconstitution of $30 \mathrm{~S}$ subunits by conventional procedure}

Forty picomoles of native $16 \mathrm{~S}$ rRNA extracted from $30 \mathrm{~S}$ subunits were incubated for $15 \mathrm{~min}$ at $42^{\circ} \mathrm{C}$ followed by $20 \mathrm{~min}$ on ice. Group I proteins containing 160 pmol each of S4, S7, S8, S15, S17, and S20 were added to native 16S rRNA with 40 units of human placenta RNase inhibitor (HPRI, Takara). Buffer conditions were adjusted to $\mathrm{R}^{\prime}$ buffer (50 mM Hepes- $\mathrm{KOH}$ [pH 7.6], 330 $\mathrm{mM} \mathrm{KCl}, 20 \mathrm{mM} \mathrm{MgCl}$, $7 \mathrm{mM}$ B-mercaptoethanol) and reaction mixtures were incubated for $20 \mathrm{~min}$ at $37^{\circ} \mathrm{C}$. Group II proteins containing 160 pmol each of S5, S6, S9, S11, S12, S13, S16, $\mathrm{S} 18$, and S19 were added to reaction mixtures with 40 units of HPRI. Buffer conditions were adjusted to $\mathrm{R}^{\prime}$ buffer, and reaction mixtures were incubated for $20 \mathrm{~min}$ at $37^{\circ} \mathrm{C}$ followed by $1 \mathrm{~h}$ at $42^{\circ} \mathrm{C}$. Group III proteins containing 160 pmol each of S2, S3, $\mathrm{S} 10, \mathrm{~S} 14$, and S21 were added to reaction mixtures with 40 units of HPRI. Buffer conditions were adjusted to $\mathrm{R}^{\prime}$ buffer, and reaction mixtures were incubated for $20 \mathrm{~min}$ at $37^{\circ} \mathrm{C}$. The final concentrations of native 16S rRNA and S2-S21 ribosomal proteins were 0.4 and $1.6 \mu \mathrm{M}$, respectively, in $100 \mu \mathrm{L}$. Reconstitution of $30 \mathrm{~S}$ subunits was analyzed by sucrose gradient sedimentation using $10 \%-40 \%$ sucrose gradients in $20 \mathrm{mM}$ Hepes- $\mathrm{KOH}$ (pH 7.6), 20 $\mathrm{mM} \mathrm{MgCl}$, and $330 \mathrm{mM} \mathrm{KCl}$ in a SW41Ti rotor at 32,000 rpm (Beckman Coulter) for $15.5 \mathrm{~h}$ at $4^{\circ} \mathrm{C}$.

\section{Purification of reconstituted 30 S subunits}

Fractions with similar sedimentation velocity in sucrose gradients as native $30 \mathrm{~S}$ subunits were collected and diluted with R buffer, followed by ultracentrifugation using a TLA100.3 rotor (Beckman Coulter) at $70,000 \mathrm{rpm}$ for $16 \mathrm{~h}$ at $4^{\circ} \mathrm{C}$ for recovery. Reconstituted $30 \mathrm{~S}$ subunits were resolved in ribosome buffer, and the concentration was measured using Gene Spec I (HITACHI). Aliquots of the reconstituted subunits were frozen at $-80^{\circ} \mathrm{C}$.

\section{Measurement of the peptide or protein synthesis activity of reconstituted $30 \mathrm{~S}$ subunits}

The final concentrations of components used in the reaction mixtures were usually $50 \mathrm{mM}$ Hepes- $\mathrm{KOH}(\mathrm{pH} 7.6), 100 \mathrm{mM}$ potassium glutamate, 5-20 mM Mg(OAc) $2,2 \mathrm{mM}$ spermidine, $1 \mathrm{mM}$ DTT, $1 \mathrm{mM}$ ATP, $1 \mathrm{mM}$ GTP, 0.5 pmol of isolated $30 \mathrm{~S}$ subunits, 0.5 pmol of native $50 \mathrm{~S}$ subunits, $56 \mathrm{~A}_{260}$ units of tRNA mix (Roche), $10 \mu \mathrm{M}{ }^{14} \mathrm{C}$-phenylalanine, $800 \mathrm{ng}$ of poly(U), $1 \mu \mathrm{g}$ of EF$\mathrm{G}, 2 \mu \mathrm{g}$ of EF-Tu, $1 \mu \mathrm{g}$ of EF-Ts, $0.33 \mu \mathrm{g}$ of PheRS, and $16 \mathrm{pmol}$ of $\mathrm{S} 1$. The total volume of the reaction mixture was $20 \mu \mathrm{L}$. The reaction mixture was incubated at $37^{\circ} \mathrm{C}$. Reactions were terminated at 60 min by spotting onto filter paper (Whatman 3MM), and the filters were submerged in ice-cold 10\% TCA. After boiling in 10\% TCA, the filters were washed twice with 10\% TCA and $100 \%$ ethanol and dried. Radioactivity was measured using a liquid scintillation counter. Protein synthesis using the PURE system was performed as described by Shimizu et al. (2005). Reaction mixtures containing 2.4 pmol of $30 \mathrm{~S}$ subunits, 2.4 pmol of native $50 \mathrm{~S}$ subunits, $1 \mu \mathrm{g}$ of $\mathrm{S} 1,{ }^{35} \mathrm{~S}$-methionine and other required components were incubated for $60 \mathrm{~min}$ at $37^{\circ} \mathrm{C}$. Synthesized proteins labeled with ${ }^{35} \mathrm{~S}$-methionine were analyzed by $15 \%$ SDS-PAGE, and the radioactivity of the product was measured. 


\section{PURE direct assay}

The final concentrations of components used in the reaction mixtures were $50 \mathrm{mM}$ Hepes- $\mathrm{KOH}$ ( $\mathrm{pH} 7.6), 150-200 \mathrm{mM}$ potassium glutamate, 5-7.5 mM MgCl $2,2 \mathrm{mM}$ spermidine, $1 \mathrm{mM}$ DTT, 50 $\mu \mathrm{M}$ acetyl coenzyme A, $1 \mathrm{mM}$ ATP, $1 \mathrm{mM}$ GTP, 0.5 pmol of native $50 \mathrm{~S}$ subunits, $56 \mathrm{~A}_{260}$ units of tRNA mix (Roche), $10 \mu \mathrm{M}{ }^{14} \mathrm{C}$-phenylalanine, $20 \mu \mathrm{g}$ of poly(U), $1 \mu \mathrm{g}$ of EF-G, $2 \mu \mathrm{g}$ of EF-Tu, $1 \mu \mathrm{g}$ of EF-Ts, $0.33 \mu \mathrm{g}$ of PheRS, 8 pmol of S1, 24 units of HPRI (Takara), 4 pmol of native 16S rRNA, 16 pmol each of S2-S21 ribosomal proteins, and $4 \mathrm{pmol}$ of each biogenesis factor. The components were incubated in a reaction volume of $20 \mu \mathrm{L}$ for $60 \mathrm{~min}$ at $37^{\circ} \mathrm{C}$. Reactions were stopped via spotting onto filter paper (Whatman 3MM) after $60 \mathrm{~min}$, and filters were submerged in ice-cold $10 \%$ TCA after spotting. Filters were washed three times with $10 \%$ TCA and $100 \%$ ethanol, dried, and counted.

\section{SUPPLEMENTAL MATERIAL}

Supplemental material is available for this article.

\section{ACKNOWLEDGMENTS}

We thank Dr. Takashi Kanamori for providing us a protein and for stimulating discussions in this project; and Mr. Yuki Ohkoshi for pilot experiments of ribosomal protein purification. The founders had no role in study design, data collection and analysis, decision to publish, or preparation of the manuscript. This work was supported in part by the Japan Society for the Promotion of Science (JSPS) KAKENHI (10J06199 to D.T.; 15K16083 to K.A.; $16 \mathrm{H02089}$ to T.U.; 26710014, 26640134, and $17 \mathrm{H05680}$ to Y.S.), the Human Frontier Science Program (RGP0008/2014 to K.H.N. and T.U.), the Astrobiology Center Project of the National Institutes of Natural Sciences (AB271004 and AB281007 to K.A.), Grant for Basic Science Research Projects from the Sumitomo Foundation (140953 to K.A.), the Strategic Programs for R\&D (President's Discretionary Fund) of RIKEN (to Y.S.), and an intramural Grant-in-Aid from the RIKEN Quantitative Biology Center (to Y.S.).

Received March 2, 2018; accepted July 25, 2018.

\section{REFERENCES}

Arnold RJ, Reilly JP. 1999. Observation of Escherichia coli ribosomal proteins and their posttranslational modifications by mass spectrometry. Anal Biochem 269: 105-112.

Bunner A, Nord S, Wikström M, Williamson J. 2010. The effect of ribosome assembly cofactors on in vitro $30 \mathrm{~S}$ subunit reconstitution. J Mol Biol 398: 1-7.

Champney SW. 1977. Kinetics of ribosome synthesis during a nutritional shift-up in Escherichia coli K-12. Mol Gen Genet 152: 259-266.

Culver G, Noller H. 1999. Efficient reconstitution of functional Escherichia coli $30 S$ ribosomal subunits from a complete set of recombinant small subunit ribosomal proteins. RNA 5: 832-843.
Daigle DM, Brown ED. 2004. Studies of the interaction of Escherichia coli YjeQ with the ribosome in vitro. J Bacteriol 186: 1381-1387.

Davis JH, Tan YZ, Carragher B, Potter CS, Lyumkis D, Williamson JR. 2016. Modular assembly of the bacterial large ribosomal subunit. Cell 167: 1610-1622.

Held WA, Mizushima S, Nomura M. 1973. Reconstitution of Escherichia coli $30 \mathrm{~S}$ ribosomal subunits from purified molecular components. J Biol Chem 248: 5720-5730.

Jewett MC, Fritz BR, Timmerman LE, Church GM. 2013. In vitro integration of ribosomal RNA synthesis, ribosome assembly, and translation. Mol Syst Biol 9: 678.

Li S-J, Hochstrasser M. 1999. A new protease required for cell-cycle progression in yeast. Nature 398: 246-251.

Li J, Haas W, Jackson K, Kuru E, Jewett M, Fan H, Gygi S, Church G. 2017. Cogenerating synthetic parts toward a self-replicating system. Acs Synth Biol 6: 1327-1336.

Maki J, Schnobrich D, Culver G. 2002. The DnaK chaperone system facilitates 30S ribosomal subunit assembly. Mol Cell 10: 129-138.

Malakhov M, Mattern M, Malakhova O, Drinker M, Weeks S, Butt T. 2004. SUMO fusions and SUMO-specific protease for efficient expression and purification of proteins. J Struct Funct Genomics 5: 75-86.

Mulder AM, Yoshioka C, Beck AH, Bunner AE, Milligan RA, Potter CS, Carragher B, Williamson JR. 2010. Visualizing ribosome biogenesis: parallel assembly pathways for the $30 \mathrm{~S}$ subunit. Science 330: 673-677.

Nord S, Bylund GO, Lövgren MJ, Wikström MP. 2009. The RimP protein is important for maturation of the $30 \mathrm{~S}$ ribosomal subunit. $J \mathrm{Mol}$ Biol 386: 742-753.

Ramakrishnan V. 2002. Ribosome structure and the mechanism of translation. Cell 108: 557-572.

Roberts M, Rabinowitz J. 1989. The effect of Escherichia coli ribosomal protein $\mathrm{S} 1$ on the translational specificity of bacterial ribosomes. J Biol Chem 264: 2228-2235.

Shajani Z, Sykes MT, Williamson JR. 2011. Assembly of bacterial ribosomes. Annu Rev Biochem 80: 501-526.

Sharma MR, Barat C, Wilson DN, Booth TM, Kawazoe M, HoriTakemoto C, Shirouzu M, Yokoyama S, Fucini P, Agrawal RK. 2005. Interaction of Era with the 30 S ribosomal subunit: implications for $30 \mathrm{~S}$ subunit assembly. Mol Cell 18: 319-329.

Shimizu Y, Inoue A, Tomari Y, Suzuki T, Yokogawa T, Nishikawa K, Ueda T. 2001. Cell-free translation reconstituted with purified components. Nat Biotechnol 19: 751-755.

Shimizu Y, Kanamori T, Ueda T. 2005. Protein synthesis by pure translation systems. Methods 36: 299-304.

Spedding G. 1990. Isolation and analysis of ribosomes from prokaryotes, eukaryotes, and organelles. In Ribosomes and protein synthesis (ed. Spedding G). IRL Press at Oxford University Press, Oxford, UK.

Talkington MW, Siuzdak G, Williamson JR. 2005. An assembly landscape for the 30S ribosomal subunit. Nature 438: 628-632.

Thurlow B, Davis JH, Leong V, Moraes TF, Williamson JR, Ortega J. 2016. Binding properties of YjeQ (RsgA), RbfA, RimM and Era to assembly intermediates of the $30 \mathrm{~S}$ subunit. Nucleic Acids Res 44: 9918-9932.

Tu C, Zhou X, Tropea J, Austin B, Waugh D, Court D, Ji X. 2009. Structure of ERA in complex with the $3^{\prime}$ end of $16 \mathrm{~S}$ rRNA: implications for ribosome biogenesis. Proc Natl Acad Sci 106: 1484314848.

Woodson S. 2011. RNA folding pathways and the self-assembly of ribosomes. Acc Chem Res 44: 1312-1319. 

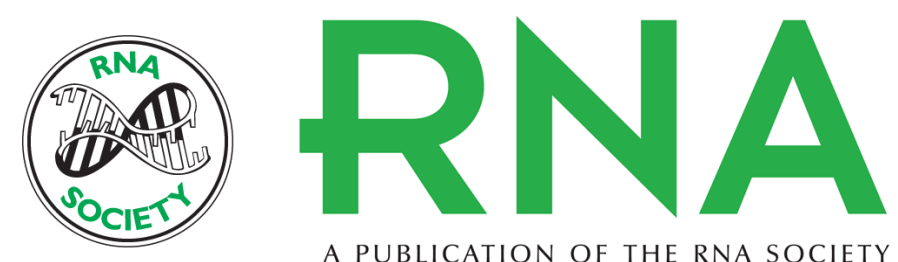

A PUBLICATION OF THE RNA SOCIETY

\section{Reconstitution of 30 S ribosomal subunits in vitro using ribosome biogenesis factors}

Daichi Tamaru, Kazuaki Amikura, Yoshihiro Shimizu, et al.

RNA 2018 24: 1512-1519 originally published online August 3, 2018

Access the most recent version at doi:10.1261/rna.065615.118

\section{Supplemental http://rnajournal.cshlp.org/content/suppl/2018/08/03/rna.065615.118.DC1 Material}

References This article cites 24 articles, 7 of which can be accessed free at: http://rnajournal.cshlp.org/content/24/11/1512.full.html\#ref-list-1

Creative This article is distributed exclusively by the RNA Society for the first 12 months after the Commons License full-issue publication date (see http://rnajournal.cshlp.org/site/misc/terms.xhtml). After 12 months, it is available under a Creative Commons License (Attribution-NonCommercial 4.0 International), as described at http://creativecommons.org/licenses/by-nc/4.0/.

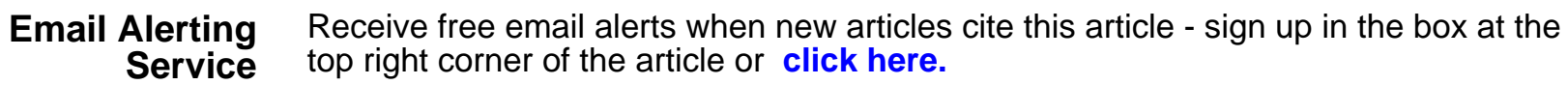

